\title{
Influence of breed and feeding on the main quality characteristics of sheep carcass and meat: A review
}

\author{
Jorge Ramírez-Retamal ${ }^{1}$, and Rodrigo Morales $^{2^{*}}$
}

\begin{abstract}
This paper reviews two factors (breed and feed) affecting the carcass and meat quality of sheep. The quality of livestock products has acquired greater importance from the distinct perspectives of the different participants in the agricultural food chain. Consumers, producers and the industry give different levels of importance to the parameters of meat and carcass quality. Nevertheless, all the participants in the meat production chain must ensure quality to improve their competitiveness. The quality of the carcass and meat can be influenced by different factors such as breed and type of feed. The breed can influence weight, yields, and the conformation of the carcass, among other variables, as well as the pH level and the fatty acid composition of the meat, whereas the feed mainly affects carcass conformation and several physicochemical and organoleptic parameters of meat quality such as proximal composition, the fatty acid profile, tenderness and color. Consequently, the effects of breed and feed type should be considered to obtain a quality product that satisfies consumer demand.
\end{abstract}

Key words: Breed, carcass, Chilote, fatty acids, grasslands, lamb, meat quality.

\section{INTRODUCTION}

The globalization of markets has resulted in greater economic integration, but at the same time has imposed the need to meet quality requirements to satisfy consumer demands. The meat industry and sheep producers must comply with certain quality standards to meet consumer demands and remain competitive in the global market. In this context, it is necessary to know the different factors that can affect the main characteristics of meat and carcass quality. Investigations have determined that age, sex (Horcada et al., 1998; Vergara et al., 1999; Barone et al., 2007), breed (Crouse et al., 1981; Hopkins and Fogarty, 1998; Kremer et al., 2004), and also the type of feed (Hopkins et al., 1995; Jacques et al., 2011) can affect the characteristics of carcass (weight, conformation, fat content, among others) and meat ( $\mathrm{pH}$, texture, instrumental color, and nutritional composition). Considering the above, the objective of this work was to review the most recent works on the effect of breed and feed (concentrates, grasslands or others) on the quality of the carcass and meat.

\footnotetext{
${ }^{1}$ Universidad Austral de Chile, Facultad de Ciencias Agrarias, Campus Isla Teja, Casilla 657, Valdivia, Chile.

${ }^{2}$ Instituto de Investigaciones Agropecuarias INIA, Ruta 5 Norte km 8, P.O. Box 24-0, Osorno, Chile.

"Corresponding author (rmorales@inia.cl).

Received: 3 September 2013.

Accepted: 14 February 2014

doi:10.4067/S0718-58392014000200015
}

\section{Situation of the ovine production sector}

According to the last national agricultural survey in Chile in 2007, there were over $3,938,059$ sheep in the country (INE, 2012b). The INE reports that between the regions of Libertador General Bernardo O'Higgins ( $34^{\circ} 10^{\prime} \mathrm{S}$, $70^{\circ} 43^{\prime} \mathrm{W}$ ) and Magallanes $\left(53^{\circ} 9^{\prime} \mathrm{S}, 70^{\circ} 55^{\prime} \mathrm{W}\right.$ ) there are around 3.5 million sheep, representing $95 \%$ of national production. In the period from January to July 2012 some 536406 sheep were slaughtered, $14.6 \%$ fewer than during the same period in 2011 (INE, 2012b). Per capita consumption in 2012 was also lower, estimated at $0.3 \mathrm{~kg}$ (INE, 2012b), which is mainly associated with the variable and seasonal consumption of ovine meat (Hervé, 2013). As well, the volume of exports in the first quarter of 2012 was $29.9 \%$ lower than during the same period a year earlier (INE, 2012b). This translates into a 35.9\% decrease in the values of exports from the previous year, for a total value of only US\$22.1 million (INE, 2012b). Nevertheless, it is estimated that real market prices globally for ovine meat and the prices paid to producers will remain the same in the coming years, although much lower than the prices in 2011 (INE, 2012a). Decreased internal consumption and exports together can be an incentive to increasing ovine herds throughout the country to meet external demand for ovine meat. Likewise, ovine production presents a higher degree of utility per hectare than other types of livestock activities in southern Chile, such as dairy farming and cattle feedlots (Vidal, 2012).

Quality does not mean the same thing to the different actors in the meat production chain. While producers and the industry are guided by more objective parameters, 
such the characteristics of the ovine carcass (Becker, 2000), consumers consider more subjective factors like the meat/fat ratio, color, tenderness and flavor (Rodrigues et al., 2006; Sepúlveda et al., 2011). This is why the quality of carcass and meat represent complex characteristics that can be difficult to evaluate (Rodrigues et al., 2006). However, if the different parameters are considered in the productive system it is possible to supply a quality product that meets the needs of both the industry and consumers and for which consumers are prepared to pay a higher price (Warner et al., 2010; Font i Furnols et al., 2011), consequently resulting in more profits for participants in the meat production chain.

\section{Quality of the ovine carcass}

The ovine carcass is defined as a "primary unit of meat resulting from the slaughter, bleeding out, skinning, gutting, and removal of the head, genitals, organs and extremities at the level of the metacarpal joint and tarsal metatarsal" according to Chilean government standards (INN, 2002).

The main criteria used to assess carcass quality are warm and cold carcass weights, because these affect other important parameters such as fat content, carcass conformation and the weight of different cuts (Díaz, 2001; Carter and Gallo, 2008; Lambe et al., 2009). Fat content is important given its impact on the price of the carcass (Díaz et al., 2002). Some of the measurements for this criterion are the thickness of the dorsal fat, the weight of renal pelvic fat, and the visual assessment of the fat content of the carcass (Díaz et al., 2002; Carrasco et al., 2009). Another variable used as a general indicator of the quality of the carcass is its conformation (Díaz, 2001), which involves a visual assessment and objective measurements such as the width and depth of the thorax, length of legs, width of the rump or the area of the rib eye, among others (Díaz, 2001).

The aforementioned factors affect to diferrent degrees the quality of the carcass and consequently the price paid to producers. All of these factors have been studied to determine if they can be influenced by sex (Thatcher et al., 1991), breed (Kremer et al., 2004), genotype (SantosSilva et al., 2002), age (Leymaster and Jenkins, 1993), weight at slaughter (Pérez et al., 2007), type of feed (Díaz et al., 2002) and productive year (Thatcher et al., 1991). The presence of contusions, which are characterized by degree, location and extension, are also important because they reduce the value of meat cuts and carcasses (Tarumán and Gallo, 2008). To the above criteria can be added the types of cuts obtained from the carcass and the ratios among different types of tissue; bone, muscle and fat (Díaz, 2001; Rodrigues et al., 2006). Table 1 presents comparative works relating the main characteristics to the quality of ovine carcasses.

There have been numerous studies on the influence of breed on carcass quality and characteristics in order to breed

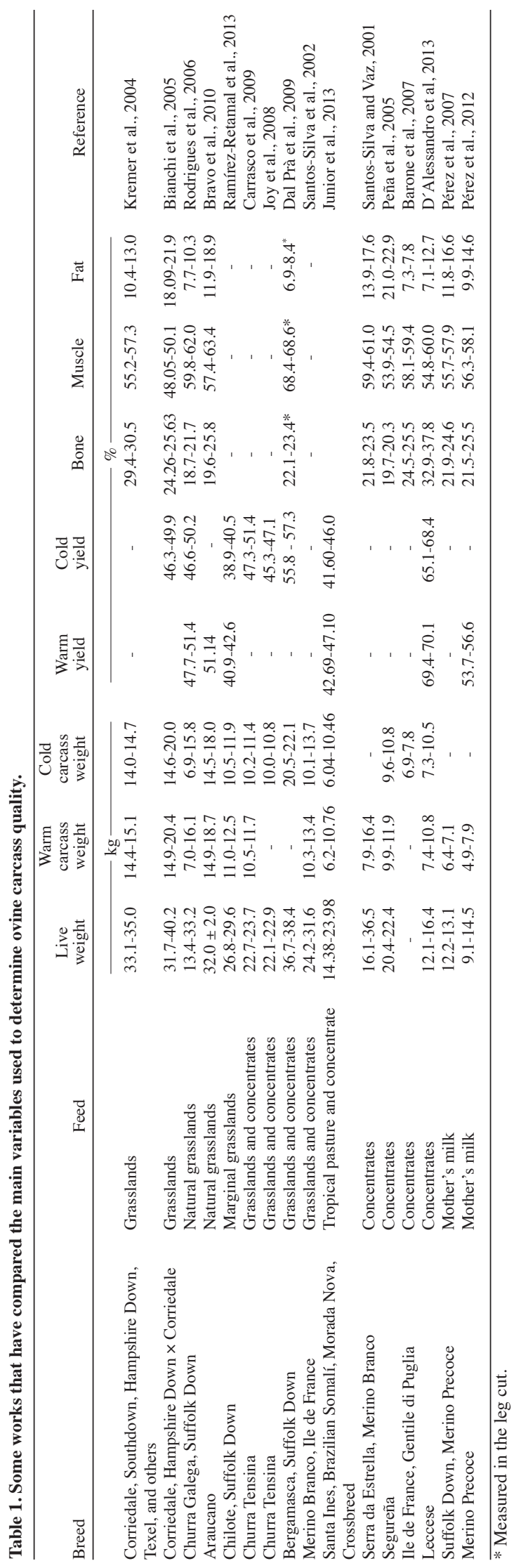


more specialized animals in response to market demands while increasing the profitability of the productive system (Crouse et al., 1981). Santos-Silva et al. (2002) compared 'Merino Branco' lambs to those from crossbreeding 'San Merino' and 'Île de France'. The lambs obtained from the crossing had better carcass yields and muscle/bone ratios, but the authors considered these differences of limited importance given that these factors do not greatly influence the commercial value of the carcass. In contrast, Rodrigues et al. (2006) found differences in the carcasses of 'Churra Galega Bragancana' and 'Suffolk Down' lambs in terms of yield and proportion of cuts obtained from the carcass, with a higher proportion of relevant cuts (leg, shoulder, and breast) obtained from the 'Suffolk Down' lambs.

There were also differences in carcass composition and fat content, with 'Suffolk Down' lambs presenting better results. Pérez et al. (2007) did not find differences between carcasses of 'Suffolk Down' and 'Merino Precoz Alemán’ lambs. Miguélez et al. (2006) compared three breeds ('Churra', 'Castellana' and 'Ojalada') belonging to Protected Geographical Indications under the European Union and found differences in some parameters (cold carcass weight, tissue and others). Barone et al. (2007) compared 'Gentile di Puglia', a breed raised for wool and meat, 'Île de France' and their cross, and found differences in characteristics of the carcasses of the two pure breeds, which were more pronounced when compared to those of the crossbred lambs. Santos-Silva and Vaz (2001) found significant differences between the carcasses of the breeds 'Serra da Estrela' and 'Merino Branco' in all the analyzed variables except carcass yield. The varying results reflect differences in development among breeds, for example muscle distribution owing to specialization in animal production (Santos-Silva et al., 2002; Rodrigues et al., 2006; Mustafa et al., 2008). A recent study comparing 'Suffolk' and 'Chilote' lambs under the productive conditions of Chiloe Island found that the rump of 'Chilote' lamb was thinner, whereas horns and hooves accounted for a higher proportion of its weight (Ramírez-Retamal et al., 2013).

There are different types of productive systems that establish feeding according to their resources, taking into account that feeding is one of the major costs in animal production. Feeding systems for lambs can be based on grazing or concentrates (Ponnampalam et al., 2010). There are also mixed systems that combine the two (Jacques et al., 2011) and systems based on mother's milk or milk substitutes (Pérez et al., 2002). The feeding system can affect the composition of the carcass (Lewis et al., 2002) and the degree of fattening. Animals fed by grazing present low levels of fat, which increases their acceptability to consumers (Sañudo et al., 2000b). Likewise, the fat of grass-fed animals tends to be yellow (Priolo et al., 2002). The carcasses of grass-fed lambs weigh less than those of lambs fed on concentrates that are slaughtered at the same age (Priolo et al., 2002), thus animals fed mainly on concentrates require less time to be prepared for slaughtering (Mustafa et al., 2008).

Despite the importance that breed and feed type have individually in determining the quality of the carcass, it is possible that the interaction between two or more factors also affects quality and characteristics of lamb carcasses (Díaz et al., 2002; Mustafa et al., 2008).

Research on carcass quality is generally conducted under optimal productive conditions and there has been relatively little research conducted under less favorable conditions (Fraser et al., 1996; Prache et al., 2011), because of which it is necessary to consider systems in which productive conditions are more restricted, such as grazing in areas with naturalized or natural grasslands. Ramírez-Retamal et al. (2013) compared the main characteristics of the carcasses of Chilote lambs feed on naturalized pasture or natural rangeland and did not find differences resulting from the grassland types used by small-scale producers in Chiloe Island, Chile.

\section{Quality of ovine meat}

A series of biochemical processes and changes at the cellular level must occur to change muscle into flesh (Pearce et al., 2011). An important stage in this process is rigor mortis, together with alterations at the myofibril level of the muscles (Pearce et al., 2011). As well, ATP and glycogen levels should decrease, this in turn causing a decrease in muscular $\mathrm{pH}$ from 7.0 to less than 6.0 (Koohmaraie et al., 1991; Ouali et al., 2006; Pearce et al., 2011).

There are several parameters to establish the quality of the meat. One of the main indicators is the $\mathrm{pH}$ of the meat (Weglarz, 2010), given that abnormal $\mathrm{pH}$ values can alter the quality of meat, especially in terms of color and tenderness (Priolo et al., 2001; Mounier et al., 2006). Levels of 5.8 or less $24 \mathrm{~h}$ after slaughter are recommended to avoid problems in meat quality (Tejeda et al., 2008). Table 2 presents some works that compared the main characteristics used to determine the quality of ovine meat.

The color of meat is an important factor influencing consumer-purchasing decisions (Moore et al., 2003). Color is influenced by the chemical status of myoglobin in the meat. Freshly cut meat has higher concentrations of desoxymyoglobin molecules, which give the meat a reddish purple color. However, after exposure to oxygen, desoxymyoglobin is transformed to oxymyoglobin, resulting in a desirable bright red color. Finally, with more exposure the meat turns brown owing to the transformation of oxymyoglobin to metamyoglobin due to oxidization (Moore et al., 2003). Meat color can be evaluated instrumentally or by a sensory panel. The instrumental approach is based mainly on the CIE system, which was developed by the Commission Internationale de l'Eclairage of France, and is the universally accepted 


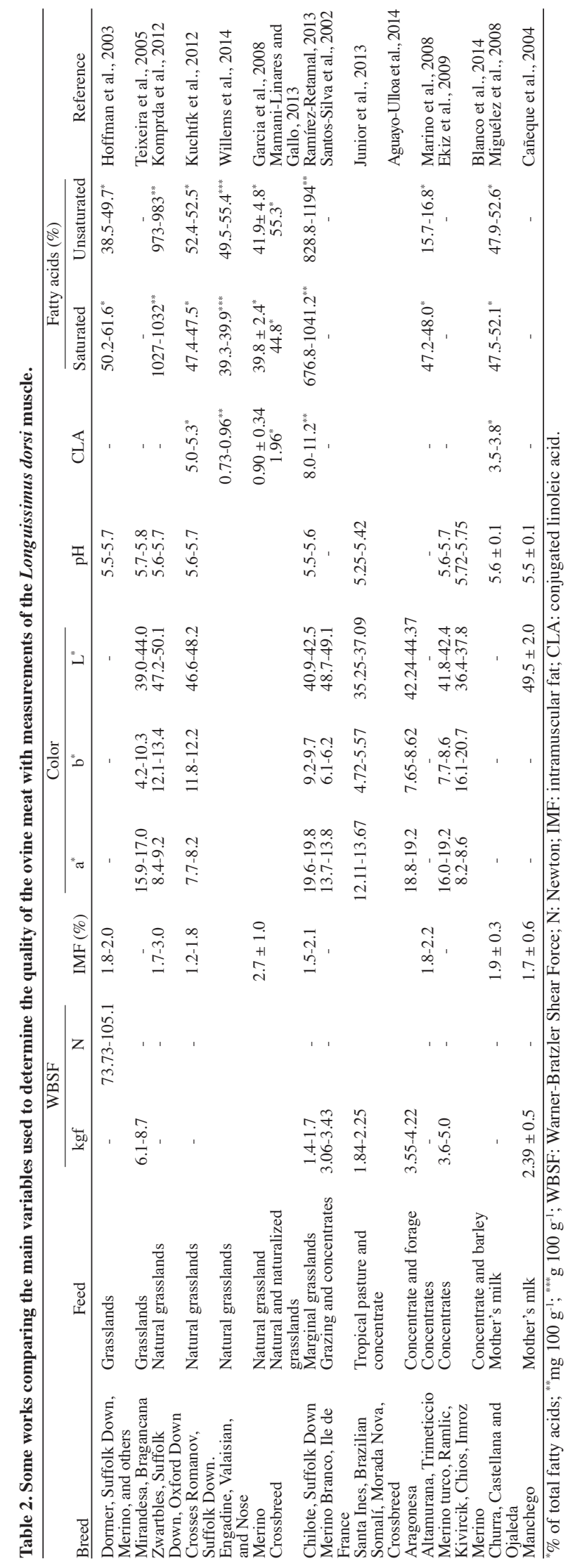

standard for color specification and measurement. It considers three fundamental aspects, namely luminosity $\left(L^{*}\right)$, red tones or redness $\left(a^{*}\right)$ and blue-yellow tones or yellowness $\left(b^{*}\right)$ (Priolo et al., 2001).

Together with juiciness and flavor, tenderness gives the sensation of pleasure when eating meat (Koohmaraie et al., 2002). The proteolysis of muscular tissue, sarcomere shortening and the solubility of connective tissue of muscular fibers are factors that can determine the degree of tenderness of meat after post mortem storage of the animal (Koohmaraie et al., 2002; Warner et al., 2010). However, the degree to which these factors affect the tenderness of the meat are variable and it is necessary to evaluate other factors like the muscular group, breed and the age of the animal (Warner et al., 2010), among others. Some authors argue that feeding strategies can also affect tenderness (Sañudo et al., 2003; Ponnampalam et al., 2003). The principal method to evaluate tenderness are the Warner-Bratzler shear force (WBSF) test in which the units of measurement are the kilograms of force needed to shear a $1 \mathrm{~cm}^{3}$ muscle sample. According to Rajalakshmi et al. (1987) meat with a shear force of 2.1 or less, as determined by the WBSF method, can be considered tender.

The influence of intramuscular fat (IMF) on tenderness and juiciness varies depending on the study and the species studied (Wood et al., 2008). With sheep, meat with more marbling or IMF is more valued by sensory panels (Fisher et al., 2000; Wood et al., 2008). Similarly, meat with a higher IMF level has a lower shear force value, which nevertheless does not directly relate the IMF level to the degree of tenderness (Sañudo et al., 2000a). The fatty acid composition of the meat is very important given its implications for human health (Givens, 2005) in relation to heart disease and cancer (Wood et al., 2003). Likewise, the fatty acid composition affects characteristics of the meat like juiciness, flavor, shelf life, and firmness of the fat (Wood et al., 2003). Polyunsaturated and saturated fatty acids and the ratio between them and the $n-6: n-3$ ratio have important implications for human health. Both ratios are considered indicators of risk factors for certain cancers and coronary heart diseases (Wood et al., 2003; De Smet et al., 2004; Givens, 2005). A value of 0.4 or higher is recommended for the polyunsaturated:saturated fatty acids ratio, whereas a value of 4.0 or less for a diet is recommended for the $n-6: n-3$ ratio (British Department of Health, 1994). Likewise, there is great interest in the qualities of polyunsaturated fats termed conjugated linoleic acids (CLAs). The abbreviation CLA is a collective term used for all positional and geometric isomers of linoleic acid with conjugated double bonds. Among them, two isomers are predominant: a) CLA cis-9, trans-11 (rumenic acid), and b) CLA trans-10, cis-12, occurring in ruminant meat and dairy products (Schmid et al., 2006) in proportions of about $75-90 \%$ and $10-25 \%$ of total CLA, respectively. The major reported 
benefits of CLAs are their anticarcinogenic, antidiabetic, antiadipogenic effects and their positive effects on the immune system (Williams, 2000; Webb and O'Neill, 2008; Scerra et al., 2011).

CLAs are formed by the partial biohydrogenation of conjugated fatty acids, mainly in the rumen, because of which they are found in major concentrations in the meat of ruminant animals such as sheep (Williams, 2000; Schmid et al., 2006). The major factors affecting biohydrogenation are ruminal $\mathrm{pH}$, the forage:concentrate ratio, and the type and level of fatty acid intake. For instance, low ruminal $\mathrm{pH}$ has a significant protective effect on linoleic and linolecnic acids. For more information see the reviews of Schmidely et al. (2008) and Glasser et al. (2008).

Vasta and Luciano (2011) suggest increasing CLA cis9, trans-11 content in meat and milk products as a strategy to enhance C18:1 trans-11 uptake in the duodenum. This is because CLA cis-9, trans-11 is also synthesized by endogenous conversion of C18:1 trans- 11 (transvaccenic acid) by the enzyme $\Delta$-9-desaturase in adipose tissue and the mammary gland (Griinari and Bauman, 1999). CLA cis-9, trans-11 synthesis increased linearly with an increase in the C18:1 trans-11 content of the diets of human subjects (Salminen et al., 1998; Turpeinen et al., 2002). The rate of C18:1 trans-11 conversion to CLA cis9, trans-11 ranges from 5 to $12 \%$ in rodents to 19 to $30 \%$ in humans (Turpeinen et al., 2002).

One of the main sources of minerals in western diets is meat, especially lamb (Reykdal et al., 2011; Polidori et al., 2011), notably providing $\mathrm{Fe}, \mathrm{Zn}, \mathrm{P}, \mathrm{K}, \mathrm{Mg}$, and Se (Sheridan et al., 2003; Osorio et al., 2007; RamírezRetamal, 2013). These minerals are essential for different biological processes (free radicals and oxygen transport, among others) and their deficiency can cause problems for the organism (Cabrera et al., 2010). As well, different minerals can be associated with the quality of meat given their influence on characteristics like color, tenderness, and oxidation (Osorio et al., 2007). However, there is very little reference information in the case of minerals independent of the factors analyzed. The main minerals found were $\mathrm{Fe}$ and $\mathrm{Zn}$. This concurs with the importance assigned to these in the literature for the greater contribution of minerals to the human diet (Hoffman et al., 2003) and the importance of lamb meat as a source of $\mathrm{Fe}$ and $\mathrm{Zn}$ compared to plant sources (Williamson et al., 2005).

The quality of sheep meat, like that of the carcass, can be affected by different factors, among them the breed. A study by Hoffman et al. (2003) of several breeds and crossings found differences among breeds in $\mathrm{pH}$ values and fatty acid composition of the meat, especially monounsaturated fatty acids, which coincided with the results of Santos-Silva et al. (2002) and Marino et al. (2008). There are also differences in the concentrations of $\mathrm{Fe}, \mathrm{K}$, and $\mathrm{Mg}$, among other minerals. However, while associated with breed, these differences may also be influenced by factors like the place of origin of the animal. Another study (Teixeira et al., 2005) found no differences in $\mathrm{pH}$ values and the fatty acid profiles of the meat of two similar breeds. Nevertheless, they found differences in the $b^{*}$ coordinate of meat color. Despite the importance that breed can have on meat quality, some authors attach more importance to other factors, such as the age of the animal and the type of feed. According to these authors, breed plays only a secondary role (Navajas et al., 2008). Latorre et al. (2011) compared four breeds of sheep ('Polled Dorset', 'White Suffolk', 'Meat Merino' and 'Corriedale') in the far south of Chile and found no differences in protein content, but did find differences in vitamin E concentrations (antioxidant), which was highest in 'Corriedale' $(0.26 \mathrm{mg})$ (Latorre et al., 2011).

The various types of productive systems are focused on meeting consumer demand for quality meat, which can have different characteristics depending on the feed used. This factor, in association with others like cultural aspects and consumer habits, determines consumer preferences There is more acceptance among European consumers of meat from animals fed on concentrates or mixed systems (forage and concentrates) (Font i Furnols et al., 2009). The $\mathrm{pH}$ level of the meat is not affected by the type of feed (Priolo et al., 2002; Velasco et al., 2004; Lanza et al., 2006). The color and luminosity of the meat, on the other hand, are affected by the feed type. The meat of grass-fed animals is darker than that of animals fed on concentrates (Alcalde and Negueruela, 2001; Priolo et al., 2001). Tenderness can also be influenced by feed, the meat of animals fed on concentrates being more tender due to the level of fat associated with this type of feed (Priolo et al., 2002), although results obtained by Sañudo et al. (2003) indicated that meat of grazing animals was more tender. Likewise, there are differences among grassland types (Lind et al., 2009).

The fatty acid profile is mainly affected by the type of feed. Independent of feed type, the P:S ratio reported for sheep meat is around 0.1-0.26 (Enser et al., 1998; Wood et al., 2003; Wood et al., 2008; Ponnampalam et al., 2010; Scerra et al., 2011). Grass-fed lambs tend to have higher concentrations of CLA cis-9, trans-11 and C18:1 trans-11. Grass-fed animals also tend to have a $n-6: n-3$ fatty acid ratio four points lower than that of lambs produced under other systems (Enser et al., 1996; 1998; Webb and O'Neill, 2008). Differences in fatty acid profiles are also reported in lambs feeding with diferent type of pastures (Whittington et al., 2006; Lind et al., 2009; RamírezRetamal, 2013). Owing to these differences, the meat of grass-fed animals is recognized as healthier. In addition, pasture-based feeding has acquired importance because consumers view resulting meat products as more natural, less contaminated and reflecting more respect for animal welfare (Hersleth et al., 2012; Vasta et al., 2012). However, some authors argue that grass-feeding has negative effects 
on productive parameters like growth rates and yield, owing to the longer period of time required to prepare animals for slaughter (Aurousseau et al., 2007; Webb and O’Neill, 2008; Scerra et al., 2011).

Despite the importance of determining meat quality for the food chain, there have been few studies on animals raised in marginal areas (Lourenço et al., 2007; Lind et al., 2009; Gallardo et al., 2011; Ramírez-Retamal, 2013), because of which there is a need to determine the effects of this on meat production. In this sense, the use of autochthonous breeds or breeds native to the area represents an opportunity to develop sustainable productive systems, but it is necessary to carry out more studies to determine if these breeds meet the quality parameters for ovine meat.

Finally, there is increasing interest in secondary compounds in some plants as potential tools to improve lamb quality. This is the case of phenolic compounds, such as condensed tannins, and of saponins and essential oils rich in terpenes (Vasta and Luciano, 2011; Jerónimo et al., 2012). The scarce information available suggests that it is possible to increase the content of CLA cis-9, trans-11 and C18:1 trans-11 in lamb by inhibiting ruminal fatty acids biohydrogenation caused by tannins (Vasta et al., 2012) as well improve the color stability of fresh lamb meat (Luciano et al., 2009). Research is needed to evaluate the effect of secondary plant compounds on animal performance and meat quality.

\section{CONCLUSIONS}

Different factors should be considered in developing an optimal ovine production system to meet the demands of industry and final consumers with a quality product. Breed is an important factor in carcass quality, but of less importance for meat quality. In contrast, feed type does have a major effect on meat quality, but less effect on carcass quality, affecting mainly conformation and fat content.

\section{ACKNOWLEDGEMENTS}

This work was funded by the Project "Recuperación y Desarrollo Ovino para la Provincia de Chiloé”, Regional Government of Los Lagos, IDI Code: 30080533-0. We are also grateful for CONICYT scholarship support to Jorge Ramírez-Retamal's Masters studies (2011-2013) at the Universidad de Austral de Chile. We also thank Dr. Emilio Ungerfeld for his comments on the present work.

\section{LITERATURE CITED}

Aguayo-Ulloa, L., G. Miranada-de la Lama, M. Pascual-Alonso, J. Olleta, M. Villarroel, C. Sañudo, et al. 2014. Effect of enriched housing on welfare, production performance and meat quality in finishing lambs: The use of feeder ramps. Meat Science 97:42-48.
Alcalde, M., and A. Negueruela. 2001. The influence of final conditions on meat colour in light lamb carcasses. Meat Science 57:117-123.

Aurousseau, B., D. Bauchart, X. Faure, A. Galot, S. Prache, D. Micol, et al. 2007. Indoor fattening of lambs raised on pasture Part 1: Influence of stall finishing duration on lipid classes and fatty acids in the longissimus thoracis muscle. Meat Science 76:241-252.

Barone, C., P. Colatruglio, A. Girolami, D. Matassino, and A. Zullo. 2007. Genetic type, sex, age at slaughter and feeding system effects on carcass and cut composition in lambs. Livestock Science 112:133-142.

Becker, T. 2000. Consumer perception of fresh meat quality: a framework for analysis. British Food Journal 102:158-176.

Bianchi, G., G. Garibotto, O. Betancur, O. Feed, J. Franco, A. Peculio, et al. 2005. Características productivas y calidad de canal y de la carne en corderos pesados Corriedale y Hampshire Down $\times$ Corriedale. Revista Argentina de Producción Animal 25:75-91.

Blanco, C., R. Bodas, N. Prieto, S. Andrés, S. López, and F. Giráldez. 2014. Concentrate plus ground barley straw pellets can replace conventional feeding systems for light fattening lambs. Smal Ruminant Research 116:137-143.

Bravo, S., M. Fabres, B. Schnettler, and N. Sepúlveda. 2010. Corporal composition and characteristics of carcass of Araucano Creole lambs. International Journal of Morphology 24:1107-1111.

British Department of Health. 1994. Nutritional aspects of cardiovascular disease. Report on Health and Social Subjects $\mathrm{N}^{\circ}$ 46. Her Majesty's Stationery Office (HMSO), The National Archives, London, UK.

Cabrera, M., A. Ramos, A. Saadoun, and G. Brito. 2010. Selenium, copper, zinc, iron and manganese content of seven meat cuts from Hereford and Braford steers fed pasture in Uruguay. Meat Science 84:518-528.

Cañeque, V., C. Pérez, S. Velasco, M. Díaz, S. Lauzurica, I. Alvarez, et al. 2004. Carcass and meat quality of light lambs using principal component analysis. Meat Science 67:595-605.

Carrasco, S., G. Ripoll, A. Sanz, J. Álvarez-Rodríguez, B. Panea, R. Revilla, et al. 2009. Effect of feeding system on growth and carcass characteristics of Churra Tensina light lambs. Livestock Science 121:56-63.

Carter, L., y C. Gallo. 2008. Efectos del transporte prolongado por vía terrestre y cruce marítimo en transbordador sobre pérdidas de peso vivo y características de la canal en corderos. Archivos Medicina Veterinaria 40:259-266.

Crouse, J., J. Busboom, R. Field, and C. Ferrell. 1981. The effects of breed, diet, sex, location and slaughter weight on lamb growth, carcass composition and meat flavor. Journal of Animal Science 53:376-386.

D’Alessandro, A., G. Maiorano, M. Ragni, D. Casamassima, G. Marsico, and G. Martemucci. 2013. Effects of age and season of slaughter on meat production oflight lambs: Carcass characteristics and meat quality of Leccese breed. Small Ruminant Research 114: 97-104.

Dal Prà, A., A. Crovetti, F. Sirtori, G. Brajon, A. Olivetti, and G. Campodoni. 2009. In vita performance and slaughter characteristics of Suffolk and Bergamasca lambs at 90 days of age. Italian Journal Animal Science 8:492-494.

De Smet, S., K. Raes, and D. Demeyer. 2004. Meat fatty acid composition as affected by fatness and genetic factors: a review. Animal Research 53:81-98.

Díaz, M. 2001. Características de la canal y de la carne de corderos lechales manchegos. Correlaciones y ecuaciones de predicción. Tesis PhD. Universidad Complutense de Madrid, Facultad Veterinaria, Madrid, España.

Díaz, M., S. Velasco, V. Cañeque, S. Lauzurica, F. Ruiz de Huidobro, C. Pérez, et al. 2002. Use of concentrate or pasture for fattening lambs and its effect on carcass and meat quality. Small Ruminant Research 43:257-268.

Enser, M., K. Hallett, B. Hewett, G.A. J. Fursey, and J.D. Wood 1996. Fatty acid content and composition of English beef, lamb and pork at retail. Meat Science 42:443-456. 
Enser, M., K.G. Hallett, B. Hewett, G.A.J. Fursey, J.D. Wood, and G. Harrington. 1998. Fatty acid content and composition of UK beef and lamb muscle in relation to production system and implications for human nutrition. Meat Science 49:329-341.

Ekiz, B., A. Yilmaz, M. Ozcan, C. Kaptan, H. Hanoglu, I. Erdogan, et al. 2009. Carcass measurements and meat quality of Turkish Merino, Ramlic, Kivircik, Chios and Imroz lambs raised under an intensive production system. Meat Science 82:64-70.

Fisher, A., M. Enser, R. Richardson, J. Wood, G. Nute, E. Kurt, et al. 2000. Fatty acid composition and eating quality of lamb types derived from four diverse breed production systems. Meat Science 55:141-147.

Font i Furnols, M., C. Realini, L. Guerrero, M. Oliver, C. Sañudo, M. Campo, et al. 2009. Acceptability of lamb fed on pasture, concentrate or combinations of both systems by European consumers. Meat Science 81:196-202.

Font i Furnols, M., C. Realini, F. Montossi, C. Sañudo, M. Campo, M. Oliver, et al. 2011. Consumer's purchasing intention for lamb meat affected by country of origin, feeding system and meat price: A conjoint study in Spain, France and United Kingdom. Food Quality Preference 22:443-451.

Fraser, T.J., S.M. Scott, and J.S. Rowarth. 1996. Pasture species effects on carcass and meat quality. Proceedings of the New Zealand Grassland Association 58:63-66.

Gallardo, M.A., R. Pulido, and C. Gallo. 2011. Fatty acid composition of longissimus dorsi muscle of Suffolk down lambs fed on different dryland forages. Chilean Journal of Agricultural Research 71:566-571.

Garcia, P.T., J.J. Casal, S. Fianuchi, J.J. Magaldi, F.J. Rodríguez, and J.A. Nancucheo. 2008. Conjugated linoleic acid (CLA) and polyunsaturated fatty acids in muscle lipids of lambs from the Patagonian area of Argentina. Meat Science 79:541-548.

Givens, D. 2005. The role of animal nutrition in improving the nutritive value of animal-derived foods in relation to chronic disease. Proceedings of the Nutrition Society 64:395-402.

Glasser, F., R. Schmidely, D. Sauvant, and M. Doreau. 2008. Digestion of fatty acids in ruminants: a meta-analysis of flows and variation factors: 2 . C18 fatty acids. Animal 2:691-704.

Griinari, J.M., and D.E. Bauman. 1999. Biosynthesis of conjugated linoleic acid and its incorporation into meat and milk in ruminants. p. 180-200. In Yurawecz, M.P., M.M. Mossoba, J.K.G. Kramer, M.W. Pariza, and G.J. Nelson (eds.) Advances in conjugated linoleic acid research. Vol. I. AOCS Press, Champaign, Illinois, USA.

Hersleth, M., T. Næs, M. Rødbotten, V. Lind, and E. Monteleone. 2012. Lamb meat-Importance of origin and grazing system for Italian and Norwegian consumers. Meat Science 90:899-907.

Hervé, M. 2013. Carne ovina: Producción, características y oportunidades en lo que hoy demanda el consumidor nacional e internacional. Oficina de Estudios y Políticas Agrarias (ODEPA), Santiago, Chile.

Hoffman, L., M. Muller, S. Cloete, and D. Schmidt. 2003. Comparison of six crossbred lamb types: sensory, physical and nutritional meat quality characteristics. Meat Science 65:1265-1274.

Hopkins, D., and N. Fogarty. 1998. Diverse lamb genotypes. 2. Meat $\mathrm{pH}$, colour and tenderness. Meat Science 49:477-488.

Hopkins, D., P. Holst, and D. Hall. 1995. Effect of grain or silage supplementation on meat quality attributes of cryptorchid lambs grazing lucerne or annual grass-clover pastures. Australian Journal of Experimental Agriculture 35:461-465.

Horcada, A., M. Beriain, A. Purroy, G. Lizaso, and J. Chasco. 1998. Effect of sex on meat quality of Spanish lamb breeds (Lacha and Rasa Aragonesa). Animal Science 67:541-547.

INE. 2012a. La carne ovina. Instituto Nacional de Estadísticas (INE), Santiago, Chile.

INE. 2012b. Producción pecuaria. Primer Semestre 2012. Instituto Nacional de Estadísticas (INE), Santiago, Chile.

INN. 2002. Canales de ovinos. NCH 1364: of 2002. Instituto Nacional de Normalización (INN), Santiago, Chile.
Jacques, J., R. Berthiaume, and D. Cinq-Mars. 2011. Growth performance and carcass characteristics of Dorset lambs fed different concentrates: Forage ratios or fresh grass. Small Ruminant Research 95:113-119.

Jerónimo, E., C.M.M. Alfaia, S.P. Alves, M.T.P. Dentinho, J.A.M. Prates, V. Vasta, et al. 2012. Effect of dietary grape seed extract and Cistus ladanifer L. in combination with vegetable oil supplementation on lamb meat quality. Meat Science 92:841-847.

Joy, M., J. Alvarez-Rodriguez, R. Revilla, R. Delfam, and G. Ripoll. 2008. Ewe metabolic performance and lamb carcass traits in pasture and concentrate-based production systems in Churra Tensina breed. Small Ruminant Research 75:24-35.

Junior, F.G., R. Lobo, M. Madruga, A. Lobo, L. Viera, and O. Facó. 2013. Genotype effect on carcass and meat quality of lambs finished in irrigated pastures in the semiarid Northeastern Brazil. Arquivo Brasileiro de Medicina Veterinária e Zootecnia 65:12081216.

Komprda, T., J. Kuchtík, A. Jarošová, E. Dračková, L. Zemánek, and B. Filipčík. 2012. Meat quality characteristics of lambs of three organically raised breeds. Meat Science 91:499-505.

Koohmaraie, M., M. Kent, S. Shackelford, E. Veiseth, and T. Wheeler. 2002. Meat tenderness and muscle growth: is there any relationship? Meat Science 62:345-352.

Koohmaraie, M., G. Whipple, D. Kretchmar, J. Crouse, and H. Mersmann. 1991. Postmortem proteolysis in longissimus muscle from beef, lamb and pork carcasses. Journal of Animal Science 69:617-624.

Kremer, R., G. Barbato, L. Castro, L. Rista, L. Rosés, V. Herrera, et al. 2004. Effect of sire breed, year, sex and weight on carcass characteristics of lambs. Small Ruminant Research 53:117-124.

Kuchtík, J., D. Zapletal, and K. Šustová. 2012. Chemical and physical characteristics of lamb meat related to crossbreeding of Romanov ewes with Suffolk and Charollais sires. Meat Science 90:426-430.

Lambe, N., E. Navajas, L. Bünger, A. Fisher, R. Roehe, and G. Simm. 2009. Prediction of lamb carcass composition and meat quality using combinations of post-mortem measurements. Meat Science 81:711-719.

Lanza, M., M. Bella, A. Priolo, D. Barbagallo, V. Galofaro, C. Landi, et al. 2006. Lamb meat quality as affected by a natural or artificial milk feeding regime. Meat Science 73:313-318.

Latorre, E., J. Karmelic, C. Quinteros, S. Reyes, y M. Vargas. 2011. Evaluación del valor nutritivo de las carnes de cordero híbridos Polled Dorset, White Suffolk, Meat Merino y raza Corriedale a los 130 y 150 días del nacimiento. In Ortega, F. (ed.) XXXVI Congreso de Sociedad Chilena de Producción Animal (SOCHIPA), Punta Arenas. Noviembre 2011. Instituto de Investigaciones Agropecuarias INIA, INIA Karampangue, Punta Arenas, Chile.

Leymaster, K., and T. Jenkins. 1993. Comparison of Texeland Suffolk-sired crossbred lambs for survival, growth, and compositional traits. Journal of Animal Science 71:859-869.

Lewis, R., G. Emmans, and G. Simm. 2002. Effects of index selection on the carcass composition of sheep given either ad libitum or controlled amounts of food. Animal Science 75:185-195.

Lind, V., J. Berg, L. Eik, J. Mølmann, E. Haugland, M. Jørgensen, et al. 2009. Meat quality of lamb: Pre-slaughter fattening on cultivated or mountain range pastures. Meat Science 83:706-712.

Lourenço, M., G. Van Ranst, S. De Smet, K. Raes, and V. Fievez. 2007. Effect of grazing pastures with different botanical composition by lambs on rumen fatty acid metabolism and fatty acid pattern of longissimus muscle and subcutaneous fat. Animal $1: 537-545$

Luciano, G., F.J. Monahan, V. Vasta, L. Biondi, M. Lanza, and A. Priolo. 2009. Dietary tannins improve lamb meat colour stability. Meat Science 81:120-125.

Mamani-Linares, L., y C. Gallo. 2013. Perfil de ácidos grasos de carne de ovino y caballo criados bajo un sistema de producción extensiva. Revista de Investigaciones Veterinarias del Perú $24: 257-263$ 
Marino, R., M. Albenzio, G. Annicchiarico, M. Caroprese, A Muscio, A. Santillo, et al. 2008. Influence of genotype and slaughtering age on meat from Altamurana and Trimeticcio lambs. Small Ruminant Research 78:144-151.

Miguélez, E., J. Zumalacárregui, M. Osorio, O. Beteta, and J. Mateo. 2006. Carcass characteristics of suckling lambs protected by the PGI "Lechazo de Castilla y León" European quality label: Effect of breed, sex and carcass weight. Meat Science 73:82-89.

Miguélez, E., J. Zumalacárregui, M. Osorio, A. Figueira, B. Fonseca, and J. Mateo. 2008. Quality traits of suckling-lamb meat covered by the protected geographical indication "Lechazo de Castilla y León” European quality label. Small Ruminant Research 77:6570.

Moore, M., I. Han, J. Acton, A. Ogale, C. Barmore, and P. Dawson. 2003. Effects of antioxidants in polyethylene film on fresh beef color. Journal of Food Science 68:99-104.

Mounier, L., H. Dubroeucq, S. Andanson, and I. Veissier. 2006. Variations in meat $\mathrm{pH}$ of beef bulls in relation to conditions of transfer to slaughter and previous history of the animals. Journal of Animal Science 84:1567-1576.

Mustafa, M., J. Chadwick, P. Akhtar, S. Ali, M. Lateef, and J. Sultan. 2008. The effect of concentrate- and silage-based finishing diets on the growth performance and carcass characteristics of Suffolk Cross and Scottish Blackface lambs. Turkish Journal of Veterinary Animal Science 32:191-197.

Navajas, E., N. Lambe, A. Fisher, G. Nute, L. Bünger, and G. Simm. 2008. Muscularity and eating quality of lambs: Effects of breed, sex and selection of sires using muscularity measurements by computed tomography. Meat Science 79:105-112.

Osorio, M., J. Zumalacárregui, B. Bermejo, A. Lozano, A. Figueira, and J. Mateo. 2007. Effect of ewe's milk versus milk-replacer rearing on mineral composition of suckling lamb meat and liver. Small Ruminant Research 68:296-302.

Ouali, A., C. Herrera-Mendez, G. Coulis, S. Becila, A. Boudjellal, L. Aubry, et al. 2006. Revisiting the conversion of muscle into meat and the underlying mechanisms. Meat Science 74:44-58.

Pearce, K., K. Rosenvold, H. Andersen, and D. Hopkins. 2011. Water distribution and mobility in meat during the conversion of muscle to meat and ageing and the impacts on fresh meat quality attributes-A review. Meat Science 89:111-124.

Peña, F., T. Cano, V. Domenech, M. Alcalde, J. Martos, A. GarcíaMartínez, et al. 2005. Influence of sex, slaughter weight and carcass weight on "non-carcass" and carcass quality in Segureña lambs. Small Ruminant Research 60:247-254.

Pérez, P., M. Maino, M. Morales, C. Köbrich, C. Bardon, and J. Pokniak. 2007. Gender and slaughter weight effects on carcass quality traits of suckling lambs from four different genotypes. Small Ruminant Research 70:124-130.

Pérez, P., M. Maino, M.S. Morales, G. Tomic, F. Aguilera, and J.I. Egaña. 2012. Meat quality and carcass characteristics of Merino Precoce suckling lambs raised under confinement in the Mediterranean semi-humid dryland of Central Chile. Ciencia e Investigación Agraria 39:289-298.

Pérez, P., M. Maino, G. Tomic, E. Mardones, and J. Pokniak. 2002. Carcass characteristics and meat quality of Suffolk Down suckling lambs. Small Ruminant Research 44:233-240.

Polidori, P., A. Ortenzi, S. Vincenzetti, and D. Beghelli. 2011. Dietary properties of lamb meat and human health. Mediterranean Journal of Nutrition and Metabolism 4:53-56.

Ponnampalam, E.N., B.J. Hosking, and A.R. Egan. 2003. Rate of carcass components gain, carcass characteristics, and muscle longissimus tenderness in lambs fed dietary protein sources with a low quality roughage diet. Meat Science 63:143-149.

Ponnampalam, E., R. Warner, S. Kitessa, M. McDonagh, D. Pethick, D. Allen, et al. 2010. Influence of finishing systems and sampling site on fatty acid composition and retail shelf-life of lamb. Animal Production Science 50:775-781.

Prache, S., P. Gatellier, A. Thomas, B. Picard, and D. Bauchart. 2011. Comparison of meat and carcass quality in organically reared and conventionally reared pasturefed lambs. Animal 5:2001-2009.
Priolo, A., D. Micol, and J. Agabriel. 2001. Effects of grass feeding systems on ruminant meat colour and flavour. A review. Animal Research 50:185-200.

Priolo, A., D. Micol, J. Agabriel, S. Prache, and E. Dransfield. 2002. Effect of grass or concentrate feeding systems on lamb carcass and meat quality. Meat Science 62:179-185.

Rajalakshmi, D., S. Dhanaraj, N. Chand, and V. Govindarajan. 1987. Descriptive quality analysis of mutton. Journal of Sensory Studies 2:93-118.

Ramírez-Retamal, J. 2013. Determinación del efecto de la raza y tipo de alimentación sobre las características de la canal y la carne de cordero criado bajo las condiciones productivas de la isla de Chiloé. Tesis Magister. Universidad Austral de Chile, Facultad de Ciencias Agrarias, Valdivia, Chile.

Ramírez-Retamal, J., R. Morales, M.E. Martínez, and R. de la Barra 2013. Effect of breed and feeding on the carcass characteristics of the Chilote breed lamb. Chilean Journal of Agricultural Research 73:48-54

Reykdal, O., S. Rabieh, L. Steingrimsdottir, and H. Gunnlaugsdottir 2011. Minerals and trace elements in Icelandic dairy products and meat. Journal of Food Composition Analysis 24:980-986.

Rodrigues, S., V. Cadavez, and A. Teixeira. 2006. Breed and maturity effects on Churra Galega Bragancana and Suffolk lamb carcass characteristics: Killing-out proportion and composition. Meat Science 72:288-293

Salminen, M.M., M. Mutanen, M. Jauhiainen, and A. Aro. 1998. Dietary trans-fatty acids increase conjugated linoleic acid levels in human serum. Journal Nutrition Biochemistry 9:93-98.

Santos-Silva, J., I. Mendes, and R. Bessa. 2002. The effect of genotype, feeding system and slaughter weight on the quality of light lambs. 1. Growth, carcass composition and meat quality. Livestock Production Science 76:17-25.

Santos-Silva, J., and A. Vaz. 2001. The effect of weight on carcass and meat quality of Serra da Estrela and Merino Branco lambs fattened with dehydrated lucerne. Animal Research 50:289-298.

Sañudo, C., M. Alfonso, A. Sanchez, P. Berge, E. Dransfield, D Zygoyiannis, et al. 2003. Meat texture of lambs from different European production systems. Australian Journal of Agricultural Research 54:551-560.

Sañudo, C., M. Alfonso, A. Sánchez, R. Delfa, and A. Teixeira 2000a. Carcass and meat quality in light lambs from different fat classes in the EU carcass classification system. Meat Science 56:89-94

Sañudo, C., M. Enser, M. Campo, G. Nute, G. María, I. Sierra, et al. 2000b. Fatty acid composition and sensory characteristics of lamb carcasses from Britain and Spain. Meat Science 54:339-346.

Scerra, M., G. Luciano, P. Caparra, F. Foti, C. Cilione, A. Giorgi, et al. 2011. Influence of stall finishing duration of Italian Merino lambs raised on pasture on intramuscular fatty acid composition. Meat Science 89:238-242.

Schmid, A., M. Collomb, R. Sieber, and G. Bee. 2006. Conjugated linoleic acid in meat and meat products: A review. Meat Science 73:29-41.

Schmidely, R., F. Glasser, M. Doreau, and D. Sauvant. 2008 Digestion of fatty acids in ruminants: A meta-analysis of flows and variation factors. 1. Total fatty acids. Animal 2:677-690.

Sepúlveda, W., M. Maza, and L. Pardos. 2011. Aspects of quality related to the consumption and production of lamb meat Consumers versus producers. Meat Science 87:366-372.

Sheridan, R., L. Hoffman, and A. Ferreira. 2003. Meat quality of Boer goat kids and Mutton Merino lambs. 1. Commercial yields and chemical composition. Animal Science 76:63-71.

Tarumán, J., y C. Gallo. 2008. Contusiones en canales ovinas y su relación con el transporte. Archivos Medicina Veterinaria 40:275279.

Teixeira, A., S. Batista, R. Delfa, and V. Cadavez. 2005. Lamb meat quality of two breeds with protected origin designation. Influence of breed, sex and live weight. Meat Science 71:530-537.

Tejeda, J., R. Peña, and A. Andrés. 2008. Effect of live weight and sex on physico-chemical and sensorial characteristics of Merino lamb meat. Meat Science 80:1061-1067. 
Thatcher, L., B. Warren, and P. Nicholls. 1991. Effects of sex and year on growth and live assessment of carcass characteristics of lambs grazing annual pastures. Australian Journal of Experimental Agriculture 31:307-314.

Turpeinen, A.M., M. Mutanen, A. Aro, I. Salminen, S. Basu, D.L. Palmquist, et al. 2002. Bioconversion of vaccenic acid to conjugated linoleic acid in humans. American Journal of Clinical Nutrition 76:504-10.

Vasta, V., and G. Luciano. 2011. The effects of dietary consumption of plants secondary compounds on small ruminants' products quality. Small Ruminant Research 101:150-159.

Vasta, V., R. Pagano, G. Luciano, M. Scerra, P. Caparra, F. Foti, et al. 2012. Effect of morning $v s$. afternoon grazing on intramuscular fatty acid composition in lamb. Meat Science 90:93-98.

Velasco, S., V. Cañeque, S. Lauzurica, C. Pérez, and F. Huidobro. 2004. Effect of different feeds on meat quality and fatty acid composition of lambs fattened at pasture. Meat Science 66:457465.

Vergara, H., A. Molina, and L. Gallego. 1999. Influence of sex and slaughter weight on carcass and meat quality in light and medium weight lambs produced in intensive systems. Meat Science 52:221-226.

Vidal, R. 2012. Evaluación del negocio ovino en la zona sur. Sago Fisur, Osorno, Chile. 17 de noviembre 2012. Todoagro, Valdivia, Chile.

Warner, R., R. Jacob, J. Hocking, M. McDonagh, K. Pearce, G. Geesink, et al. 2010. Quality of lamb meat from the Information Nucleus Flock. Animal Production Science 50:1123-1134.
Webb, E., and H. O'Neill. 2008. The animal fat paradox and meat quality. Meat Science 80:28-36.

Weglarz, A. 2010. Meat quality defined based on $\mathrm{pH}$ and colour depending on cattle category and slaughter season. Czech Journal of Animal Science 55:548-556.

Whittington, F.M., R. Dunn, G.R. Nute, R.I. Richardson, and J.D. Wood. 2006. Effect of pasture type on lamb product quality. p. 27-31. 9th Annual Langford Food Industry Conference 'New Developments in Sheepmeat Quality', Bristol, UK. 24-25 May. Proceedings of the British Society of Animal Science, London, UK.

Willems, H., M. Kreuzer, and F. Lieber. 2014. Alpha-linolenic and linoleic acid in meat and adipose tissueof grazing lambs differ among alpine pasture types withcontrasting plant species and phenolic compoundcomposition. Small Ruminant Research 116:153-164.

Williams, C. 2000. Dietary fatty acids and human health. Annals of Zootechnology 49:165-180.

Williamson, C.S., R.K. Foster, S.A. Stanner, and J.L. Buttriss. 2005. Red meat in the diet. Nutrition Bulletin 30(4):323-355.

Wood, J., M. Enser, A. Fisher, G. Nute, P. Sheard, R. Richardson, et al. 2008. Fat deposition, fatty acid composition and meat quality: A review. Meat Science 78:343-353.

Wood, J., R. Richardson, G. Nute, A. Fisher, M. Campo, E. Kasapidou, et al. 2003. Effects of fatty acids on meat quality: A review. Meat Science 66:21-32. 